\title{
Fish Biology and Fishery of Oreochromis niloticus in Bahr Shebeen Canal, Delta of Egypt
}

\author{
El-Sayed A. Khallaf *; Alaa A. Alnenaei and Rehab M. Elgindy \\ Zoology Department, aculty of science, Minoufeya University, Egypt \\ *ekhallaf@yahoo.com
}

\section{ABSTRACT}

This study is a part of the project of Protecting Bahr Shebeen Canal and Procedures for Developing its Fishery Resources. Oreochromis niloticus is the main fish caught in that canal. Its biological characters; such as growth in length, lengthwight relationship, gonadosomatic index, stomachsomatic index, were studied.

Certain irregularities in reproduction and feeding were noticed, and attributed to climate change, as the year 2015 was announced to be the most hot year in 137 years. Fish mortality, as well as the average age or length of the fish in the catch, indicated that fishing is concentrated on the third year $(2.67 \mathrm{yrs})$ of life of the fish, or $13.3 \mathrm{~cm}$ in length. Those findings are discussed and accordingly, recommendations were given.

Keywords: Fishery, Oreochromis niloticus, Bahr Shebeen Canal

\section{INTRODUCTION}

In a developing country, like Egypt, sustaining and maintaining natural resources is a valuable target to increase their ability to produce food. In concomitance, inland waters occupy important place because of its fishery production. Those represent $80 \%$ of the fish production in Egypt total landings.

The main catch is composed of tilapias (Oreochromis niloticus and Tilapia zillii). This is due to the used fishing gears which are mainly directed to fishing tilapias. This project was proposed for studying the physico-chemical characteristics of this Canal, and the biology of $O$. niloticus, in order to protect and develop its fishery resources.

\section{MATERIALS AND METHODS}

\section{Study area:}

Bahr Shebeen Canal (BSC, Fig. 1), is an important water and fishery resource throughout three governorates in the Egyptian delta. It is a semi-independent water ecosystem from the Nile but connected to it by Alrayah Almenoufi near the Barrage , is a shallow [ca. 2-3 m] and narrow [ca. $30 \mathrm{~m}$ ] irrigation canal. As indicated by Khallaf and Alne-na-ei (1987) it runs for more than $80 \mathrm{~km}$ through the Egyptian Delta, surrounded by two major cities, various villages, and cultivable lands, while shore plants are rare due to human interference, especially in towns vicinity because of shore protection works.

\section{Samples collection}

Fish specimens were collected monthly from commercial fishing with trammel nets at various localities within $25 \mathrm{~km}$ length of BSC during consecutive months for 1 year (November 2014 to November 2015). Fish samples were collected with records on date of capture, standard and total lengths (to the nearest $0.1 \mathrm{~cm}$ ), body weight (to the nearest $0.1 \mathrm{gm})$, sex, maturity stages and gonads weight. Fish scales (10-20 from each specimen) were taken from the left side of each fish from the region behind the 
pectoral fin between the dorsal fin and lateral line as suggested by Rounsefell and Everhart (1953).

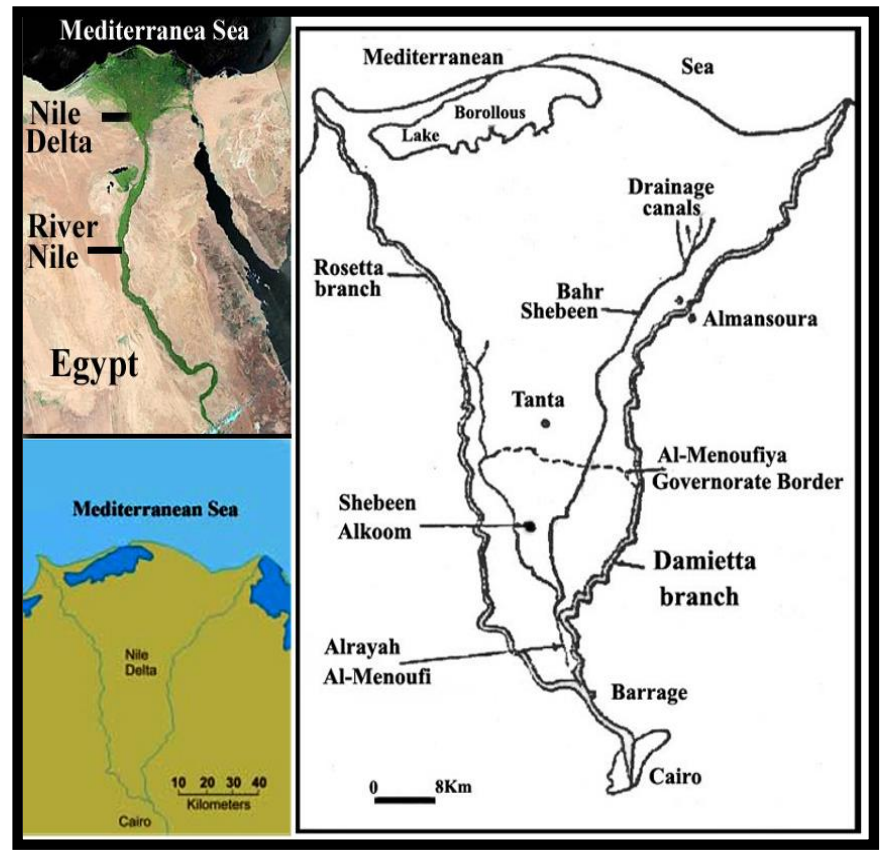

Fig. 1: Bahr Shebeen canal in the Egyptian Delta.

The scales were placed in solution of $10 \%$ of $\mathrm{NH}_{4} \mathrm{OH}$ for 24 hours, then washed with distilled water, dried with filter paper and mounted between two glass slides and examined for annuli reading and measurements. Age determination was based on the examination of the scales through a binuclear microscope at $X 10$ magnification, and annuli were distinguished, according to Lagler (1956).

Statistics:

All statistical analyses were calculated, at the 0.05 level of significance.

\section{RESULTS}

\section{Fish morphological characters:}

To manage the fish morphological data, standard length or total length is used. To facilitate calculations, the fish total and standard lengths are found to correlate (Fig. 2) as follows:

$\mathrm{Y}($ standard length, $\mathrm{cm})=0.7518 \mathrm{X}($ total length, $\mathrm{cm})+0.8127$, where $\mathrm{r}^{2}=0.8357$.

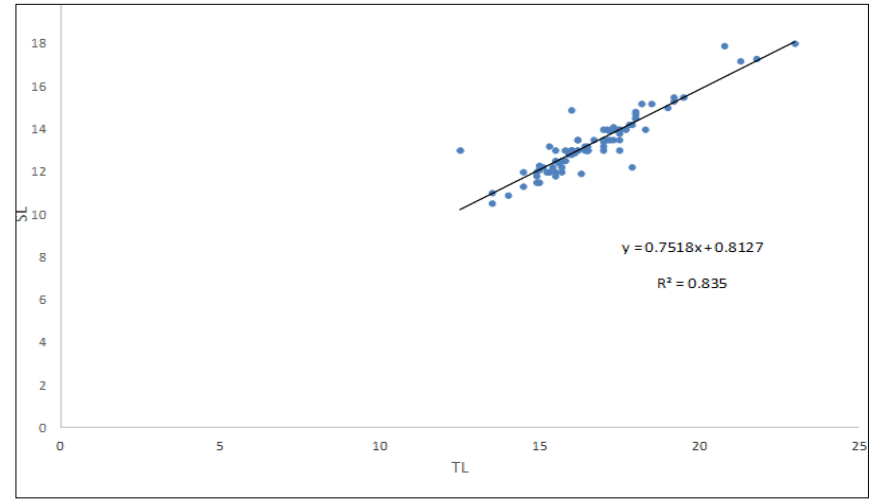

Fig. 2: Relationship between total and standard lengths of $O$. niloticus. 
The fish weight - length relationship is found to be: $\mathrm{W}(\mathrm{g})=0.066 \mathrm{Tl}(\mathrm{cm})^{2.5948}, \mathrm{r}^{2}=0.75$, (Fig. 3). and $\mathrm{W}(\mathrm{g})=0.1191 \mathrm{SL}(\mathrm{cm}){ }^{2.5899}$, $\mathrm{r}^{2}=0.78$, (Fig. 4 ).

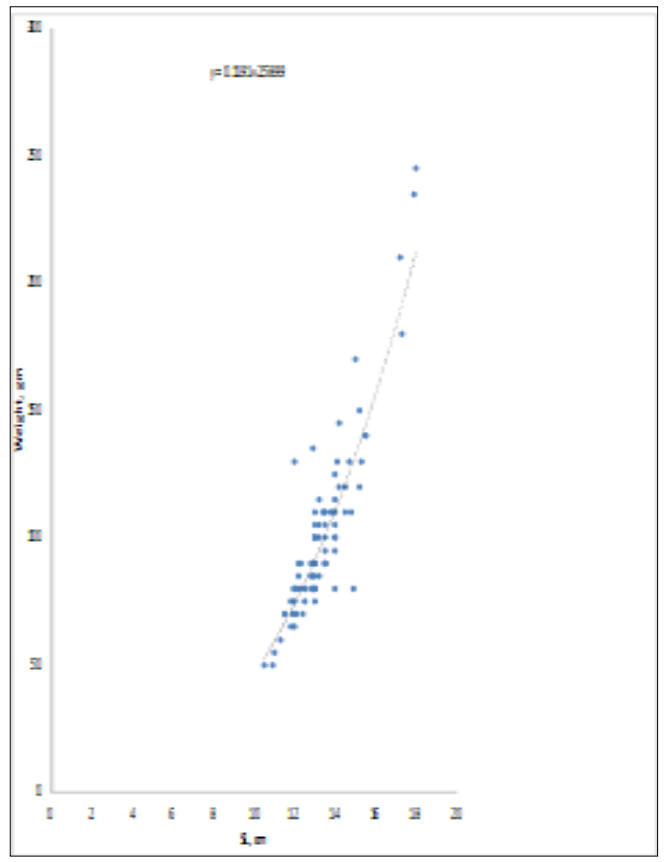

Fig. 3: Relationship between weight and standard length of $O$. niloticus.

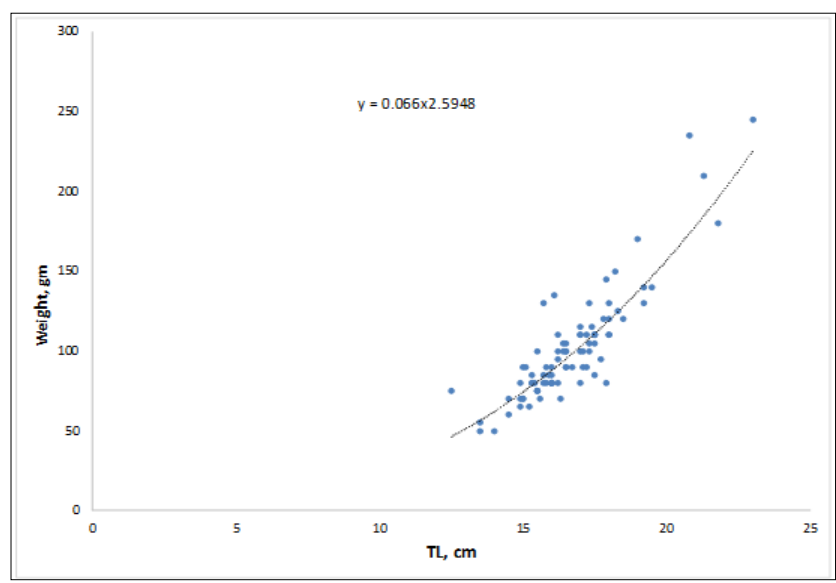

Fig. 4: Relationship between weight and total length of $O$. niloticus.

However, Khallaf (1992) indicated that O. niloticus had the slope of 2.7889. This indicates a decline in the fish condition in this canal.

\section{Age characteristics:}

\section{Age and standard length:}

This relationship gave a straight line (Fig. 5), and expressed as follows:

$\mathrm{Sl}(\mathrm{cm})=0.465(\mathrm{~A})+11.815, \mathrm{r} 2=0.7148$, where $\mathrm{A}=$ age as number of years. When the quantity $-\mathrm{a} / \mathrm{b}$ of this relationship, were calculated, it gave the maximum attainable length of $25.41 \mathrm{~cm}$.

The age and annual increment in length was examined (Fig. 6); it gave a linear relationship as follows: 
Inc $(\mathrm{cm})=-6.635(\mathrm{~A})+17.71, \mathrm{r} 2=0.8067$, the line cuts the axis at the value of age $=2.67 \mathrm{yrs}$.

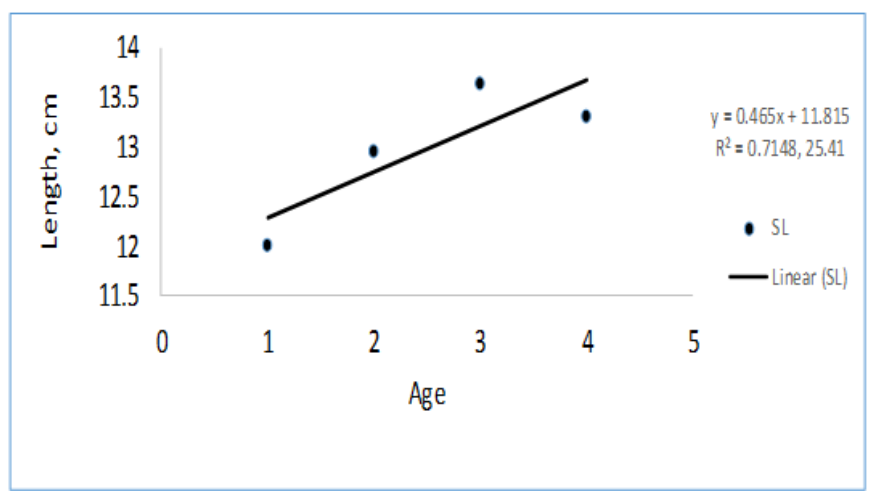

Fig. 5: Relationship between age and standard length of $O$. niloticus.

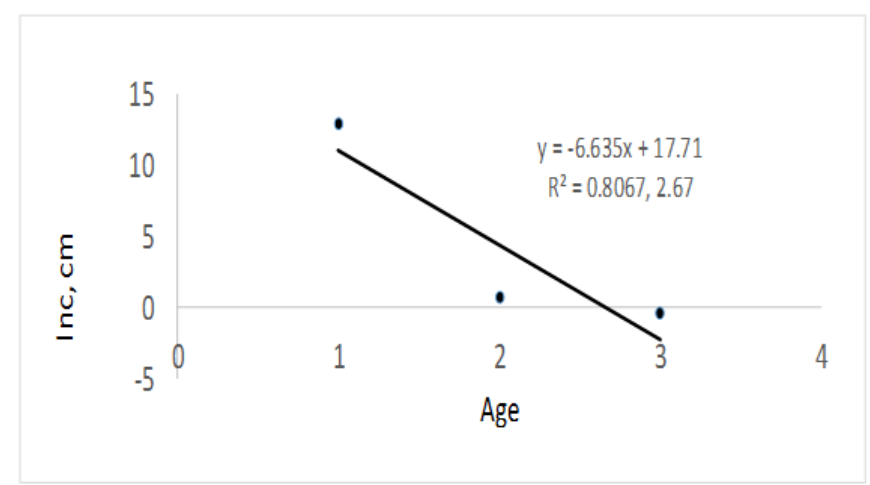

Fig. 6: Relationship between age and length increment of O. niloticus.

The Catch curve (Fig. 7), shows a peculiar shape, where the ascending limb covers the age groups I and II. However, the descending limb is only restricted to age group III. In verification, the maximum age to be attained is 2.67 , and the average length in the catch was 13.3.

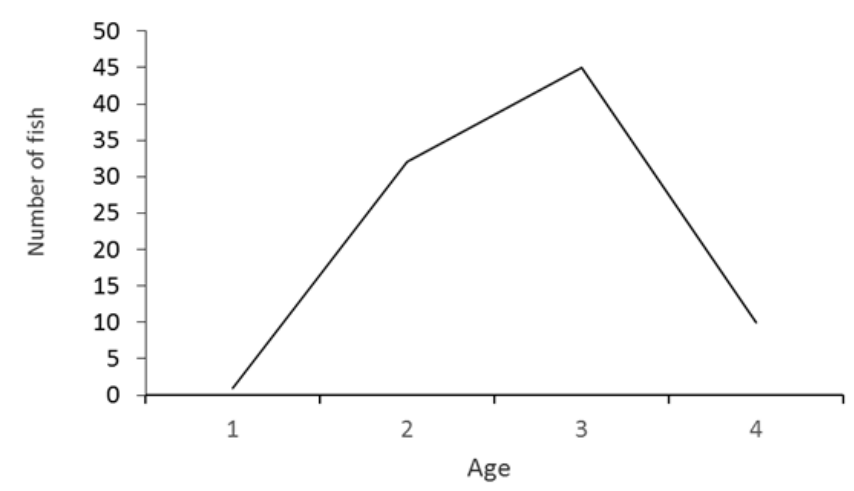

Fig. 7: Catch curve of $O$. niloticus from Bahr Shebeen canal.

Because of those findings, mortality or survival rates, as suggested by Paranov (in Ricker, 1975) could not be predicted by catch curve. However, the survival rate was calculated as indicated by Ricker (1975), as follows:

$\mathrm{S}=\sum \mathrm{N}-\mathrm{N}_{0} / \sum \mathrm{N}=0.632$.

But the Robson and Chapman model (in Ricker 1975) gave: 
$\mathrm{S}=\mathrm{T} / \sum \mathrm{N}+\mathrm{T}-1=0.639$.

In other words, the survival rate of $O$. niloticus ranges around $63 \%$, but when the age group III, the survival rate is found for II/III, to be: $\mathrm{N}_{t+1} / \mathrm{N}_{t}=0.22$, or only $22 \%$. This emphasizes the pressure of fishing on this species.

\section{Fish reproduction:}

O. niloticus, in BSC is a multiple spawner (Khallaf et al., 1986), consequently when the monthly gonadosomatic and stomach somatic index (Fig. 8) are examined, it showed two peaks in June and December (2015). The stomach somatic index had two peaks, but in August and December.

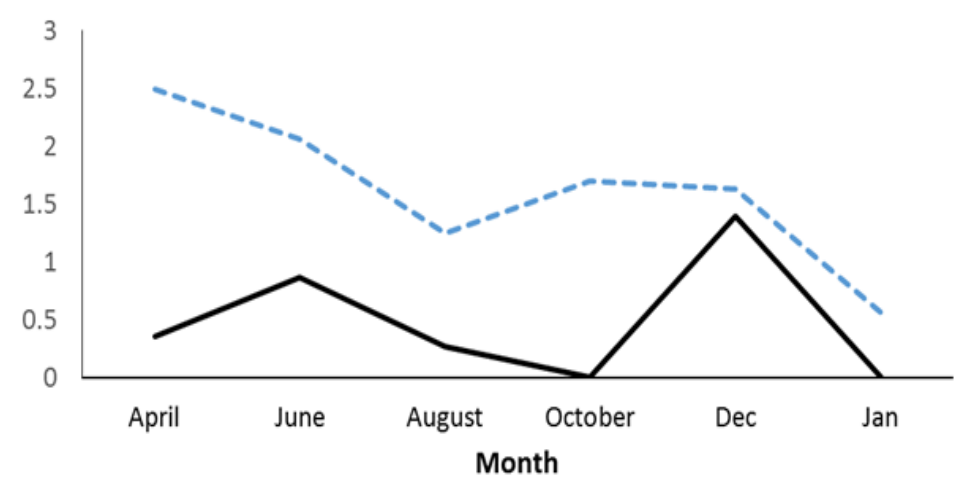

Fig. 8: Monthly variation of gonadosomatic (line) and stomach somatic index (Dashes) for O. niloticus.

Those findings were different from earlier works on the studied fish from this canal as indicated by Khallaf et al. (1986), Khallaf and Alnenaei (1987) and Khallaf (1992).

Those irregularities might be explained by the change in the climate. According to NOAA (US National Oceanic and Atmospheric Foundation), the year 2015 was considered the most hot year since weather records began 137 years. The rise in temperature has a certain effect intervening with the reproductive and feeding habits of the fish.

The stress of fishing among other, such as climate change and pollution, should be minimized by increasing the mesh size of the fishing gears.

\section{ACKNOWLEDGEMENT}

The authors express their thanks and appreciation for the Research Projects Fund at the University of Minoufiya, for their financial support of this research.

\section{REFERENCES}

Khallaf, Elsayed A.; Latif, A.F. A and Aine-na-ei, A. A. (1986). Reproduction of Tilapia nilotica and $T$. zillii in a Nile canal and its interaction with the environment. Delta J. Sci., 10(2): 724- 747.

Khallaf, Elsayed A. and Aine-na-ei, A.A. (1987). Feeding ecology of Oreochromis niloticus (Linnaeus) \& Tilapia zillii in a Nile Canal. Hydrobiologia, 146: 57 -62.

Khallaf, Elsayed A. (1992). Evaluation of the fisheries of Oreochromis niloticus at Bahr Shebeen Canal- Nile Delta, Egypt. Egypt. Ger. Zool. Soc. J. 7 B: 27-44. 
Lagler, K. F. (1956). Freshwater Fishery Biology. Iowa, USA: W. M. C. Brown Co. Dubuque.

Le Cren, E. D. (1951). "The length-weight relationship and seasonal cycle in gonad weight and condition in the perch (Perca fluviatilis)," J. Anim. Ecol., 20(2): 201-219.

Ricker, W. E. (1975). Handbook of computations and interpretations of biological statistics of fish production. Canada: Bull. Fish. Res. Bd. Canada, 191: 382 p.

Rounsfell, G. A. and Everhart, W. H. (1953). Fishery science its method and application. John Wiley \& Sons. NY, USA.

\section{ARABIC SUMMARY}

بيولوجيا ومصايد اسماك البلطى النيلى "أوريوكروميس نيلوتيكاس" من ترعة بحر شبين بالدلتا المصرية.

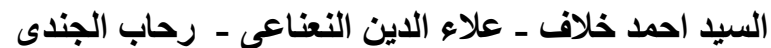

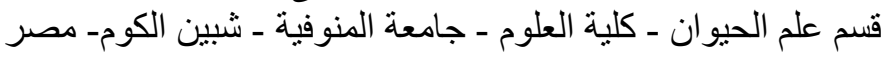

تشكل هذه الدر اسة جز ع من مشروع "حماية ترعة بحر شبين وآليات تتمية الثروة السمكية بها". تمثل

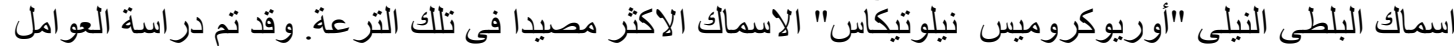

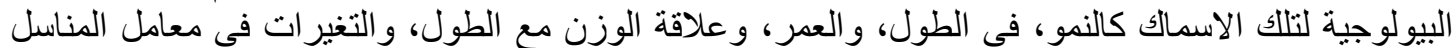

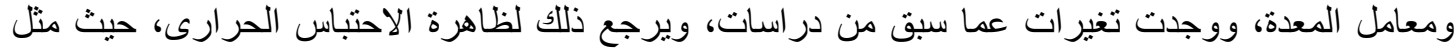

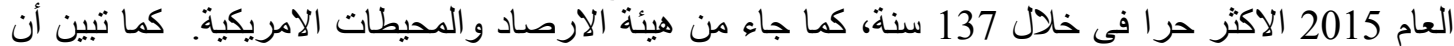

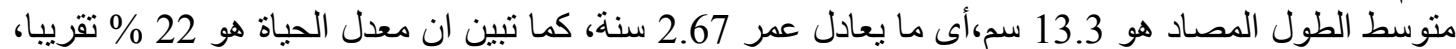

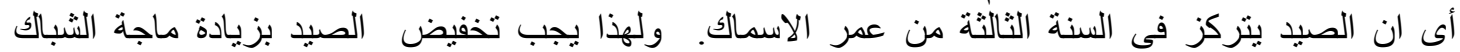

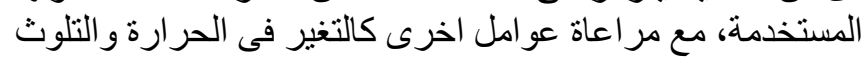

